\title{
CLONING OF DOUBLE STRANDED DNA CODING FOR HORDEIN POLYPEPTIDES.
}

\author{
by \\ ANDERS BRANDT \\ Department of Psysiology. Carlsberg Lahoratory. \\ Gamle Carlsberg Vej 10. DK-2500 Copenhagen Valby
}

Keywords: Hordein, messenger RNA, reverse transcription, molecular cloning

Double stranded $\mathrm{CDNA}$ was synthesized from a partially purified hordein mRNA preparation isolated from developing barley endosperm. The double stranded CDNA was inserted by homopolymeric tailing into the Hind IIJ site of plasmid pBR322. Following hacterial transformation one recombinant plasmid which contains an 850 base pair insert was shown to hybridize to the mRNAs coding for two of the B-hordein polypeptides.

\section{INTRODUCTION}

The storage protein of the barley endosperm. termed hordein, comprises a number of polypeptides differing in molecular weight, charge and peptide maps $(17,20,21)$. Considerable varietal heterogeneity of hordein polypeptide sizes has been reported $(25,26)$ and genetic analysis have revealed that these polymorphisms in the polypeptide group of C-hordein are determined by one and those of the B-hordein by another locus on barley chromosome $5(12,22,24,26)$. The chymotryptic peptide maps of individual hordein polypeptides synthesized in vitro have shown similarities, suggesting homology of their primary structure (17). Hordein polypeptides are synthesized on the rough endoplasmic reticulum of the endosperm cell $(4,13)$ as larger sized precursors (5), which are vectorially discharged into the lumen of the endoplasmic reticulum ( 7. $8)$ and then deposited in protein bodies $(18,28)$. Hordein polypeptides may amount to $50 \%$ of the total protein in the barley endosperm and hordein mRNAs can be isolated in large amount from the endosperm during the stage of hordein biosynthesis (5).

Abbreviations: HEPES $=\mathbb{X}$-2-hydroxyethylpiperazine- $N$-2-cthane sulphonic acid: PIPES = piperazine- $\mathbb{N} N^{*}$ bis (2-ethane sulphonic acid); SIS = sodium dodecyl sulphate: SSC - $0.15 \mathrm{~m}-\mathrm{NaCl} .0 .015 \mathrm{~m}-\mathrm{Va}$-citrate: $7 \mathrm{CA}$ = trichloroacetic acid: TRIS = tris (hydroxymethyl)-amino methan. $\mathrm{CDNA}$ - complementary D.VA: kh -kilobases: $\mathrm{mRNA}=$ messenger RNA. 
By reverse transcription of messenger RNA (mRNA) and molecular cloning nucleotide sequences coding for endosperm storage polypeptides of maize have recently been isolated with the purpose of defining the organization of the genes for the zein polypeptides (29). Similarily, reverse transcription and cloning of complementary DNA (cDNA) derived from mRNA is used in the present work to study the organization and expression of hordein genes. A double stranded cDNA sequence, derived from a partially purified mRNA population coding for the hordein polypeptides has been cloned in E. coli. The cDNA sequence was found to code for two of the B-hordein polypeptides.

\section{MATERIALS AND METHODS}

\subsection{Chemicals}

Avian myeloblastosis virus reverse transcriptase was obtained from Dr. J. BEARD, Life Sciences, Inc., St. Petersburgh, Florida, by courtesy of the Virus Cancer Program, U.S. National Cancer Institute (batch G-978). E. coli DNA polymerase I grade I and calf thymus terminal transferase were obtained from Boehringer, Mannheim; S-1 nuclease and tRNA from Sigma, St. Louis; Poly-U sepharose $4 \mathrm{~B}$ and SPsephadex C-50 from Pharmacia, Sweden; Oligo (dT) ${ }_{12-18}$ from Collaborative Research Inc. USA; and ${ }^{3} \mathrm{H}$ and ${ }^{32} \mathrm{P}$ labelled deoxynucleotide triphosphates from Amersham, England. Rabbit reticulocyte lysate and ${ }^{35} \mathrm{~S}$-methionine were obtained from New England Nuclear, USA, and the restriction enzymes Hind III, Eco RI, Pst I, Sal I, Hpa I, and Hpa II from New England Biolabs, USA.

\subsection{Plant material}

Barley plants (Hordeum vulgare L.) cv. Bomi were grown and endosperms isolated as previously described $(4,5)$.

\subsection{Isolation of $\mathrm{mRNA}$}

Membrane bound polysomes were isolated by the procedure described in BAULCOMBE and Verma (1). Polyadenylated RNA was extracted from total cells or from membrane bound polysomes, sedimented in a sucrose gradient, and the 11S peak containing hordein mRNA collected as described previously (5).

\section{4. cDNA synthesis}

cDNA was synthesized essentially as described by Buell et al. and Wickens et al. $(6,30)$.

First strand synthesis was performed in $50 \mathrm{~mm}$-TRIS/HCl, pH 7.3, $10 \mathrm{~mm}-\mathrm{MgCl}_{2}, 30$ mM- $\beta$-mercaptoethanol, $140 \mathrm{~mm}-\mathrm{KCl}, 0.5 \mathrm{~mm}$ of dTTP, dGTP, dCTP, $250 \mu \mathrm{Ci}^{3} \mathrm{H}$ dATP $(29 \mathrm{Ci} /$ nmole), $100 \mu \mathrm{g} \cdot \mathrm{ml}^{-1}$ of oligo $(\mathrm{dT})_{12-18} \cdot 10 \mu \mathrm{g}$ mRNA and $200 \mathrm{U}$ reverse transcriptase in a final volume of $150 \mu \mathrm{l}$. This mixture was incubated for 1 hour at $42{ }^{\circ} \mathrm{C}$, then cooled to $4^{\circ} \mathrm{C}$ and made $10 \mathrm{~mm}$ in EDTA and $0.2 \mathrm{M}$ in $\mathrm{NaOH}$. The RNA was hydrolyzed by heating the mixture for $30 \mathrm{~min}$ at $68^{\circ} \mathrm{C}$. The preparation was then cooled and neutralized by adding $1 / 10$ vol of 2 м-Na-acetate pH 5.2. After extraction with phenol in the presence of carrier tRNA the aqueous phase was passed through a $10 \mathrm{ml}$ column of SP-sephadex C50 equilibrated in 20 $\mathrm{mm}-\mathrm{NaCl}$. The void volume was collected, made $0.4 \mathrm{M}$ in $\mathrm{NaCl}$ and the DNA precipitated in ethanol.

The precipitate was redissolved and second strand synthesis was performed in $100 \mathrm{~mm}$ HEPES pH 6.9, $0.5 \mathrm{~mm}$ of dATP, dGTP, dCTP and $250 \mu \mathrm{Ci}^{3} \mathrm{H}$-dTTP $(43 \mathrm{Ci} /$ nmole). $50 \mathrm{U} \mathrm{E}$. coli DNA polymerase I was then added and the synthesis carried out for 2 hours at $15^{\circ} \mathrm{C}$ in a final volume of $200 \mu 1$. The reaction was stopped by adding SDS to $0.1 \%$ and EDTA to $5 \mathrm{~mm}$, and the mixture phenol extracted before the aqueous phase was passed through a $10 \mathrm{ml}$ column of SP-sephadex C50 equilibrated in 20 mм- $\mathrm{NaCl}$. The void volume was collected and adjusted to $0.3 \mathrm{~m}-\mathrm{NaCl}, 30 \mathrm{~mm}-\mathrm{Na}$-acetate, 3 $\mathrm{mm}-\mathrm{ZnCl}_{2}, \mathrm{pH} 4.5$ by adding $1 / 10$ volume of a tenfold concentrated stock solution. The sample was incubated with $100 \mathrm{U}$ of $\mathrm{S} 1$-nuclease for 1 hour at $37^{\circ} \mathrm{C}$ to cut the terminal hairpin (16) The reaction mixture was then phenol extracted with tRNA as carrier and the DNA in the aqueous phase ethanol precipitated.

\subsection{Tailing reaction and annealing}

The plasmid pBR 322 was prepared, $0.4 \mu \mathrm{g}$ digested with Hind III and added to a $100 \mu \mathrm{l}$ 
reaction mixture containing $140 \mathrm{~mm}$-cacodylic acid, $30 \mathrm{~mm}$-TRIS base, $1 \mathrm{~mm}-\mathrm{CoCl}_{2}, 0.1 \mathrm{~mm}$ dithiothreitol, $50 \mu \mathrm{g} \cdot \mathrm{ml}^{-1}$ bovine serum albumin, $5 \mu \mathrm{Ci}{ }^{32} \mathrm{P}$-thymidine triphosphate $(300$ $\left.\mu \mathrm{Ci} \cdot \mathrm{mmole}^{-1}\right)$ and 26 units of calf thymus terminal transferase (11).

Double stranded cDNA was tailed in a similar way except that the $100 \mu l$ reaction micture contained $5 \mu \mathrm{Ci}{ }^{32} \mathrm{P}$-deoxyadenosine triphosphate $\left(350 \mu \mathrm{Ci} \cdot \mathrm{mmole}^{-1}\right)$. The reaction for thymidine tailing was carried out for $5 \mathrm{~min}$ at $25^{\circ} \mathrm{C}$ and that for deoxyadenosine tailing for 5 $\min$ at $37^{\circ} \mathrm{C}$

SDS and EDTA were added to $0.1 \%$ and 5 $\mathrm{mM}$, respectively, the two reaction mixtures were pooled, and the mixture extracted with I volume phenol:chloroform:isoamylalcohol $\quad(50: 50: 1)$. The aqueous phase was adjusted to $0.4 \mathrm{~m}-\mathrm{NaCl}$ and the nucleic acid precipitated with ethanol. The precipitate was taken up in $50 \mu \mathrm{l} 0.1 \mathrm{~m}$ $\mathrm{NaCl}, 10 \mathrm{~mm}$-Tris- $\mathrm{HCl}, 1$ mм-EDTA pH 8.0 and heated for $10 \mathrm{~min}$ at $68^{\circ} \mathrm{C}$. It was then incubated for 1 hour each at $46^{\circ} \mathrm{C}, 37^{\circ} \mathrm{C}$ and $23^{\circ} \mathrm{C}$.

\subsection{Transformation}

E. coli HB 101 cells were grown in $50 \mathrm{ml} \mathrm{LB}$ broth (1\% Bacto Tryptone, $0.5 \%$ Bacto yeast extract, $0.5 \% \mathrm{NaCl}, 0.1 \%$ glucose) to an optical density of $0.6 \mathrm{~A}_{600} \cdot \mathrm{ml}^{-1}$. The cells were made competent for transformation and transformed as described by LeDERBERG and COHEN (19). Recombinant colonies were screened on LB agar plates containing $20 \mu \mathrm{g} \cdot \mathrm{ml}^{-1}$ ampicillin and replica plated on plates containing $100 \mu \mathrm{g} \cdot \mathrm{ml}^{-1}$ tetracycline.

\subsection{Colony hybridization}

The procedure used was a modification of that of Grunstein and Hogness (14). Colonies grown on Millipore filters were lysed in $0.5 \mathrm{M}$ $\mathrm{NaOH}$, neutralised in $1.0 \mathrm{~m}-\mathrm{Tris}-\mathrm{HCl} \mathrm{pH} 7.5$ and finally washed with $0.5 \mathrm{~m}-\mathrm{T}$ ris- $\mathrm{HCl} \mathrm{pH} 7.5$, $1.5 \mathrm{M}-\mathrm{NaCl}$. The filters were then placed on a vacuum manifold and vacuum applied. $400 \mathrm{ml}$ of $96 \%$ ethanol was passed through each filter, which were then air dried and heated for 2 hours at $80^{\circ} \mathrm{C}$. Filters were soaked in Denhardt's solution $(0.02 \%$ Ficol $400,0.02 \%$ polyvinyl- pyrrolidone, $0.02 \%$ bovine serum albumin) with $5 \times$ SSC containing sheared E. coli DNA (20 $\left.\mu \mathrm{g} \cdot \mathrm{ml}^{-1}\right)$. Hybridization was performed with $2 \times 10^{6}{ }^{32} \mathrm{P}$ labelled $\mathrm{cDNA}$ as a probe for 18 hours at $68{ }^{\circ} \mathrm{C}$ in a slowly rotating sealed $40 \mathrm{ml}$ tube. Following hybridization filters were extensively washed in $2 \times S S C$ at $68^{\circ} \mathrm{C}$, air dried and autoradiographed at $-70^{\circ} \mathrm{C}$ with Kodak X-omat film using intensifying screens.

\subsection{Isolation of plasmid DNA}

Cultures of recombinant colonies were grown to $\mathrm{OD}_{600}=1.2$ before amplification of plasmid DNA by addition of $150 \mu \mathrm{g} \cdot \mathrm{ml}^{-1}$ chloramphenicol (9). Plasmid DNA was extracted as described by Clewell and Helinski (10) followed by ethidium bromide- $\mathrm{CsCl}$ equilibrium gradient centrifugation and acid-phenol extraction (31).

\subsection{Restriction endonuclease treatment of DNA}

Restriction endonuclease treatment of DNA was carried out in $10 \mathrm{~mm}$-Tris- $\mathrm{HCl} \mathrm{pH} 7.8,10$ $\mathrm{mm}-\mathrm{MgCl}_{2}, 10 \mathrm{~mm}-\beta$-mercaptoethanol with 50 $\mathrm{mm}-\mathrm{NaCl}$ for Hind III, Sal I, Pst I, Hpa I, Hpa II, $100 \mathrm{~mm}-\mathrm{NaCl}$ for Eco RI and $150 \mathrm{~mm}$ $\mathrm{NaCl}$ for Bam HI. The reactions were carried out for 2 hours at $37^{\circ} \mathrm{C}$ and the nucleases inactivated by heating for $10 \mathrm{~min}$ at $68^{\circ} \mathrm{C}$.

\subsection{Hybrid arrested translations}

The conditions of PatTerson et al. (23) were used for hybrid arrested translation. Eco RI digested recombinant plasmid DNA $(2 \mu \mathrm{g})$ was hybridized for 2 hours at $48^{\circ} \mathrm{C}$ to $10 \mu \mathrm{g}$ of total cellular poly $\mathrm{A}^{+}$RNA in $100 \mu 180 \%$ formamide $0.4 \mathrm{~m}-\mathrm{NaCl}, 10 \mathrm{~mm}$-PIPES $\mathrm{pH} 6.4$. The samples were divided in two of which one was heated for $1 \mathrm{~min}$ at $100^{\circ} \mathrm{C}$ as a control, rapidly cooled in a dry ice-propanol bath and ethanol precipitated. The nucleic acids were collected by centrifugation and the pellet freeze dried to remove any remaining ethanol before the RNA was translated in the rabbit reticulocyte lysate as described by the supplier (New England Nuclear). TCA precipitable translation products were analysed as described previously (5). 


\subsection{DNA gel-electrophoresis}

DNA was analysed on horizontal agarose slab gels in $90 \mathrm{~mm}$-Tris-borate, $1 \mathrm{~mm}$-EDTA buffer pH 8.4 at $2 \mathrm{~V} \cdot \mathrm{cm}^{-1}$ for 18 hours. The gels were stained with $\mathrm{I} \mu \mathrm{g} \cdot \mathrm{ml}^{-1}$ ethidium bromide in the electrophoresis buffer and photographed under longwave ultraviolet irradiation using $\mathrm{LV}$ - and orange filters.

\subsection{Containment}

Handling of cells containing recombinant DNA was carried out under P2 conditions (15). The experiments were registered with the Committee on Genetic Engineering of the Danish National. Research Councils.

\section{RESULTS}

\subsection{Synthesis of double stranded cDNA}

Hordein mRNA was partially purified from the membrane bound polysomes of barley endosperm by poly (U)-sepharose chromatography and sucrose gradient centrifugation. This procedure yielded a mRNA fraction which was essentially free of ribosomal RNA and enriched in hordein mRNA activity (5). This mRNA preparation was used as a template for single stranded cDNA synthesis using avian myeloblastosis virus reverse transcriptase. The yield of single stranded cDNA was variable, but of the order of $10 \%$ of the mRNA template present in the reaction. All of the label incorporated into single stranded cDNA was accessible to S-1 nuclease digestion, after removal of the mRNA by alkaline hydrolysis. Synthesis of the second strand of the cDNA molecule by E. coli DNA polymerase $I$ resulted in a double stranded cDNA resistant to $\mathrm{S}-1$ nuclease digestion. The size of this DNA was estimated to be 50-2000 base pairs by electrophoresis in agarose gels.

\subsection{Insertion of double stranded cDNA in pBR322 and transformation}

The bacterial plasmid vector used for cloning of the double stranded cDNA was pBR322 (2). The plasmid was linearized with the restriction endonuclease Hind III and the $3^{\prime}-\mathrm{OH}$ ends of the molecule tailed by addition of approx. 30 residues of thymidine using calf thymus terminal deoxynucleotidyl transferase. After removal of the hairpin loops at the end of the double stranded CDNA the $3{ }^{\prime}-\mathrm{OH}$ ends were similarly extended with 30 residues of deoxyadenosine. The addition of homopolymeric tails to the DNA molecules was linear with time for more than 15 minutes and no initial lag in the addition of tails was observed. Tailed plasmid DNA was annealed with tailed double stranded CDNA with a five times excess of plasmid DNA and the annealed DNA was then used to transform E. coli HB101 cells. Table I shows the number of ampicillin resistant colonies obtained when various DNA preparations were used for transformation. 326 colonies were obtained using recombinant DNA and a background of 23 colonies were found when linearized and tailed pBR322 alone was applied. This background is $0.06 \%$ of the transformation observed with the native plasmid and may be due to the presence of intact $\mathrm{pBR}$ molecules after the Hind III restriction endonuclease treatment. It has been reported that insertion of sequences up to several megadaltons in size into the Hind III site of pBR322 lead to 90 to $99 \%$ loss of tetracycline resistance (3). Thus in order to identify recombinant clones the colonies were replicated to plates with a rather high concentration of tetracycline $\left(100 \mu \mathrm{g} \cdot \mathrm{ml}^{-1}\right)$. The majority $(96.3 \%)$ of the colonies transformed with pBR322-cDNA were tetracycline sensitive.

The ampicillin resistant, tetracycline sensitive colonies were further screened for longer inserts by colony-DNA hybridization using ${ }^{32} \mathrm{P}$-labelled cDNA as a probe (Figure 1). 12 colonies were found which contained recombinant plasmids with double stranded cDNA inserts long enough to be detected under these conditions.

Plasmids were isolated from cultures of these colonies and the size of the plasmids determined by agarose gel electrophoresis. Most of the plasmids has inserts of less than 100 base pairs but one plasmid was found to have a larger insert.

\subsection{Hybrid-arrested translation}

The recombinant plasmid containing the largest insert was characterized by hybridarrested translation. Total cellular polyadenylated RNA was hybridized to an excess of plasmid linearized with restriction endonuclease Eco RI. Following hybridization, the reaction mixture 
Table I

Cloning of double stranded cDNA derived from hordein messenger RNA.

\begin{tabular}{|c|c|c|}
\hline $\begin{array}{l}\text { Phenotype of } \\
\text { bacterial clone }\end{array}$ & $\begin{array}{l}\text { DNA used for } \\
\text { transformation }\end{array}$ & $\begin{array}{c}\text { Transformation } \\
\text { efficiency } \\
\text { Bacterial clones } \cdot \mu \mathrm{g} \text { vector } \mathrm{DNA}^{-1}\end{array}$ \\
\hline $\begin{array}{l}\text { Ampicillin } \\
\text { resistant }\end{array}$ & $\begin{array}{l}\text { pBR } 322 \text { closed } \\
\text { circular DNA }\end{array}$ & 40,000 \\
\hline $\begin{array}{l}\text { Ampicillin } \\
\text { resistant }\end{array}$ & $\begin{array}{l}\text { pBR322, Hind III } \\
\text { digested dT tailed }\end{array}$ & 23 \\
\hline $\begin{array}{l}\text { Ampicillin } \\
\text { resistant }\end{array}$ & $\begin{array}{l}\text { pBR322, dT tailed } \\
+ \text { cDNA, dA tailed }\end{array}$ & 326 \\
\hline $\begin{array}{l}\text { Ampicillin resistant, } \\
\text { tetracycline sensitive }\end{array}$ & $\begin{array}{l}\text { pBR322, dT tailed } \\
\text { + cDNA, dA tailed }\end{array}$ & 314 \\
\hline $\begin{array}{l}\text { Ampicillin resistant, } \\
\text { tetracycline sensitive, } \\
\text { DNA hybridizes with } \\
\text { 32P-cDNA }\end{array}$ & $\begin{array}{l}\text { pBR322, dT tailed } \\
\text { + cDNA, dA tailed }\end{array}$ & 12 \\
\hline
\end{tabular}

Figure 1. Detection of E. coli clones containing recombinant plasmids. Colonies were grown on Millipore filters, lysed and hybridized to ${ }^{32} \mathrm{P}$-labelled cDNA as described under Materials and Methods 2.7. The autoradiogram shows 5 colonies containing DNA hybridizable to the cDNA.

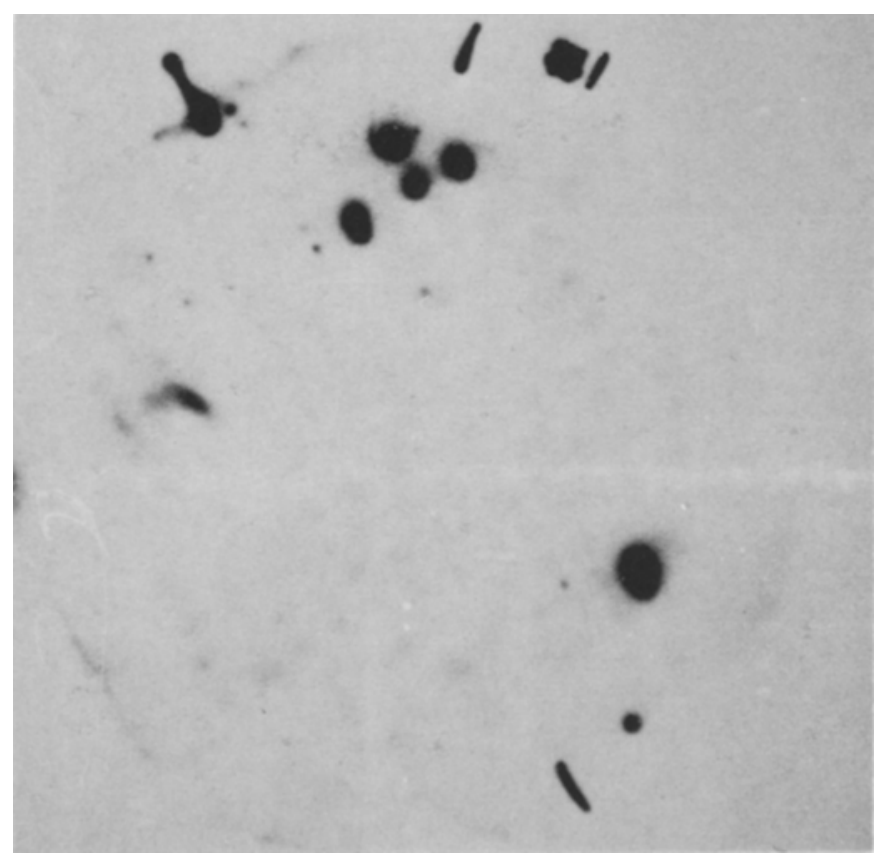




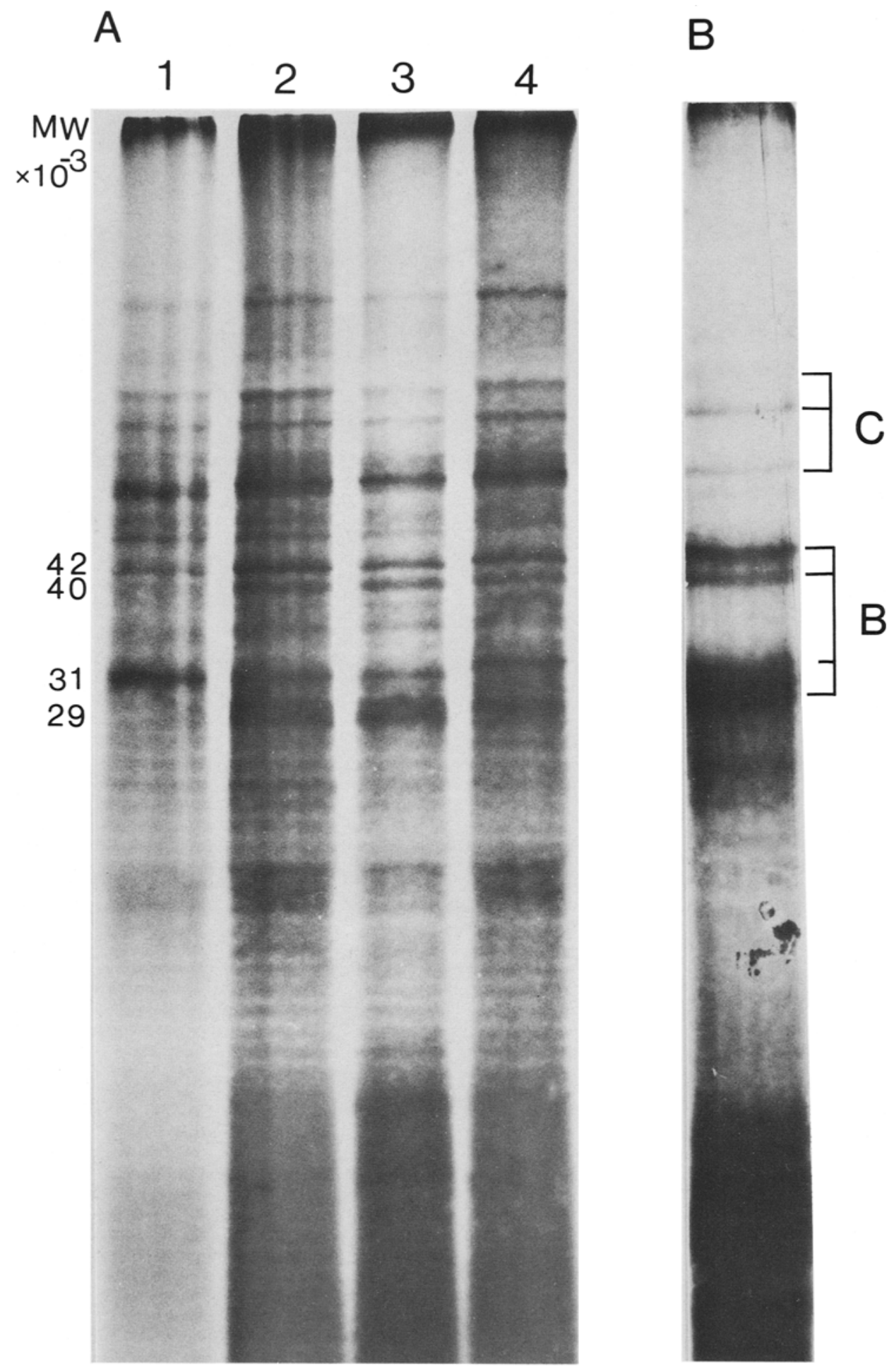


was divided into two samples. One was heated to denature any mRNA-DNA hybrids as a control prior to translation of both samples in the reticulocyte lysate.

Among the in vitro translation products synthesis of a 29 kilodalton polypeptide was completely and that of a 40 kilodalton polypeptide partially arrested by the hybrid plasmid (Figure 2A, track 1). Upon melting of the DNARNA hybrids, the synthesis of these two polypeptides was restored (Figure 2A, track 2). Eco RI digested $\mathrm{pBR} 322$ added under conditions allowing DNA-mRNA hybridization did not affect translation of any of the polypeptides obtainable in vitro from total cellular polyadenylated RNA isolated from the barley endosperm (Figure 2A, tracks 3 and 4).

Hordein precursor polypeptides have previously (5) been shown to be the primary translation products of endosperm total cellular polyadenylated RNA in the wheat germ cell-free protein synthesizing system (Figure 2B). Polypeptides with the same apparant molecular weight are synthesized in the reticulocyte lysate protein synthesizing system (Figure 2A). They were shown all to be soluble in $55 \%$ isopropanol. The wheat germ system gives rise to more low molecular weight material which is probably due to premature polypeptide chain termination. It is concluded that the cloned cDNA sequence in the recombinant plasmid is complementary to two mRNAs coding for two precursor hordein polypeptides in the B-hordein group with molecular weights of 29 and 40 kilodaltons, respectively.

Figure 2. Hybrid-arrested translation. Fluorograms of cell-free translation products using polyadenylated mRNA isolated from endosperms of Bomi barley.

A: Translation in the rabbit reticulocyte lysate system. Track 1: ${ }^{35} \mathrm{~S}$-methionine labelled polypeptides translated from mRNA after its hybridization to the cDNA containing plasmid. Track 2: The mRNA hybridized to CDNA was melted by heat prior to translation. Track 3: ${ }^{35} \mathrm{~S}$-methionine labelled polypeptides translated from mRNA mixed with $\mathrm{pBR} 322$ under conditions allowing hybridization. Track 4: The mRNA hybridized to pBR322 was melted prior to translation

B: Track 1: ${ }^{35} \mathrm{~S}$-methionine labelled polypeptides translated from mRNA in the wheat germ system.

\subsection{Size and restriction endonuclease mapping of the cloned hordein cDNA sequence}

The circular closed molecule of the native recombinant plasmid had a larger apparent molecular weight than pBR322 (Figure 3A). The size of the inserted hordein CDNA sequence and the restriction endonuclease map of the inserted sequence was established by compairing the fragment sizes derived from the recombinant plasmid and pBR322 using restriction endonucleases which only have one cleavage site on pBR 322. Treating the recombinant plasmid with restriction endonucleases Eco RI, Hind III and Bam HI, respectively, resulted in a 5.0 kilobase pair linear molecule (Figure 3A, tracks 5,6,9) as compared to a 4.36 kilobase pair fragment for pBR322. Since by the procedure used in this study the original recognition site on pBR322 for Hind III was destroyed, the inserted sequence must have a Hind III site to produce the linear molecule of 5.0 kilobase pairs seen in Figure 3A. The recognition sequences for Eco RI and Hind III of pBR322 are only 30 base pairs apart (27). An Eco RI site of the inserted sequence near the Eco RI site of pBR322 would therefore not be detected by this analysis. Digestion with Pst I resulted in two fragments of 4.2 and 0.8 kilobase pairs in size. Consequently the inserted sequence appears to have one Pst I site.

By pairwise restriction endonuclease digestion, the restriction site in the inserted sequence could be determined relative to the known (27) restriction endonuclease sites on pBR322. Digestion of the recombinant plasmid with Pst I and Eco RI yielded three fragments of 4.10, 0.95 and 0.25 kilobase pairs in length. Consequently the Pst I site in the inserted sequence maps 0.25 kilobase pairs from the Eco RI site and 4.1 kilobase pairs from the Pst I site on pBR322, respectively (Figure 3B, tracks 2 and 3). By similar analysis the Pst I and the Hind III sites on the inserted sequence were localized relative to known sites on pBR322 and relative to each other (Figure 3B, tracks 4 to 11). The fragment sizes obtained are given in Table II and the results of the mapping presented graphically in Figure 4.

The following distances can be derived from the analysis: The Pst I - Eco RI digest of the recombinant plasmid yields a new fragment of $0.25 \mathrm{~kb}$ defining the distance between the Eco RI 




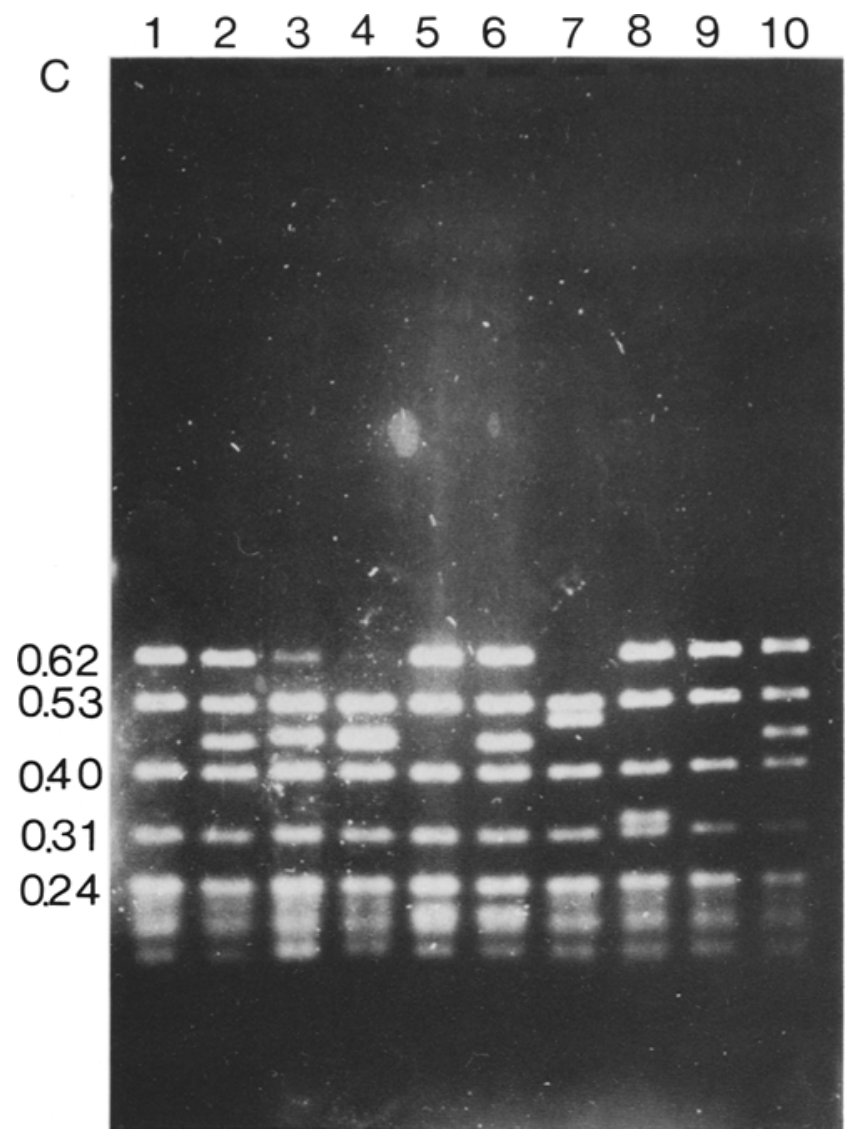

Figure 3. Restriction endonuclease analysis of the recombinant plasmid.

A: Single restriction endonuclease digestion patterns. The fragments were separated on a $0.8 \%$ (upper $2 / 3$ ) and $1.5 \%$ (lower 1/3) agarose gel. Track 1: Size marker (kb). $\lambda$ DNA digested with Eco RI. Track 2: Native pBR322 (major band is closed circular DNA). Track 3: Native recombinant plasmid (major band is closed circular DNA). Track 4: pBR322 digested with Eco RI. Tracks 5 to 9: Recombinant plasmid digested with Eco RI (track 5), Hind III (track 6), Sal I (track 7), Pst I (track 8), Bam HI (track 9). Track 10: Size marker. $\lambda$ DNA digested with Eco RI + Hind III.

B: Double enzyme digestion patterns. The frag- ments were separated on a $1.2 \%$ agarose gel. Track 1: Size marker (kb). A mixture of $\lambda$ DNA digested with Eco RI and Eco RI + Hind III. Tracks 2, 4, 6 , 8, 10: pBR322 DNA. Tracks 3, 5, 7, 9, 11 Recombinant plasmid DNA. Tracks 2 and 3: Pst I + Eco RI. Tracks 4 and 5: Pst I + Bam HI. Tracks 6 and 7: Pst I + Hind III. Tracks 8 and 9: Hind III + Eco RI. Tracks 10 and II: Hind III + Bam HI.

C: Double enzyme digestion patterns. The fragments were separated on a $2 \%$ agarose gel. Tracks 1 . 3, 5, 7, 9: pBR322 DNA. Tracks 2, 4, 6, 8, 10: Recombinant plasmid DNA. Tracks 1 and 2: Hpa II. Tracks 3 and 4: Hpa II + Eco RI. Tracks 5 and 6: Hpa II + Bam HI. Tracks 7 and 8: Hpa II + Hind III. Tracks 9 and 10: Hpa II + Pst I. site and the Pst I site in the insertion to be $\sim 250$ base pairs. This would make the distance between the pBR322 Pst I site and the new Pst I site $\sim 1000$ base pairs in agreement with the extra fragment in the Pst I digest of the recombinant plasmid of $\sim 950$ base pairs. The Pst I - Bam HI digest of the recombinant yields two fragments of similar size around 950 base pairs in agreement with the location of the insertion Pst I site midways between the Bam I and Pst I site of pBR322. The double digest Pst I - Hind III of the recombinant plasmid places the insertion Hind III site $\sim 600$ base pairs from the insertion Pst I site. The combination of Eco RI and Hind 
A. Brandt: Hordein cDNA

TABLE II

Sizes of fragments in kilobases obtained by digestion of the recombinant plasmid with different combinations of restriction endonucleases.

\begin{tabular}{lll}
\hline Restricion endonucleases & \multicolumn{2}{c}{ Fragment size, $\mathrm{kb}^{\mathrm{a})}$} \\
& recombinant plasmid & $\mathrm{pBR} 322(27)$ \\
\hline Bam HI & 5.00 & 4.36 \\
Eco RI & 5.00 & 4.36 \\
Hind III & 5.00 & 4.36 \\
Pst I & $4.10,0.95$ & 4.36 \\
Pst I - Eco RI & $4.10,0.95,0.25$ & $3.61,0.95$ \\
Pst I - Bam HI & $3.24,0.96,0.94$ & $3.24,1.12$ \\
Pst I - Hind III & $3.58,1.00,0.60$ & $3.58,0.78$ \\
Hind III - Eco RI & $4.33,0.84$ & 4.33 \\
Hind III - Bam HI & $4.70,0.3$ & $4.01,0.35$ \\
& & \\
Hpa II ${ }^{\text {b) }}$ & 0.44 & $-0.62,+0.46$ \\
Hpa II - Eco RI & $0.46,0.44$ & $-0.62,+0.49$ \\
Hpa II - Bam HI & 0.44 & \\
Hpa II - Hind III & $0.62,0.33,-0.49$ & \\
Hpa II - Pst I & 0.44 & \\
\hline
\end{tabular}

a) The fragment sizes were determined using $\lambda$ DNA digested with Eco RI and Eco RI - Hind III as markers for the larger fragments and pBR322 digested with Hpa II as markers for the smaller fragments (27).

b) Only the sizes of the additional or missing fragments compared to the Hpa II fragments $0.62,0.53,0.40$, $0.31,0.24 \mathrm{~kb}$ obtained from pBR322 are given.



Figure 4. Restriction endonuclease map of the hordein specific insert. Cross marked heavy line depict the insert and thin line pBR322 DNA. The cleavage sites for the various restriction endonucleases are indicated above the line.

III digestion places this Hind III site $\sim 840$ base pairs from the Eco RI site. The Hind III site in the insertion of the recombinant plasmid must be very close to the end of the inserted sequence as the Hind III - Bam HI digest of the recombinant and original plasmid yields a $\sim 350$ base pair fragment (Figure 3B, tracks 10 and 11 ), which is also close to the map distance between the Bam $\mathrm{HI}$ and the Hind III sites in pBR322 (346 base pairs). Since in $\mathrm{pBR} 322$ the distance between the Eco RI site and the Hind III site is only 30 base pairs the inserted hordein sequence can be cut out almost quantitatively by Eco RI plus Hind III digestion of the recombinant plasmid (cf. Figure $3 \mathrm{~B}$, track 9). This fragment was estimated to contain $840 \pm 50$ base pairs. The mapping results in a comparable value of about 850 base pairs. 


\section{A. BRANDT: Hordein cDNA}

The restriction endonuclease $\mathrm{Hpa}$ II also cleaved the inserted sequence (Figure $3 \mathrm{C}$, Table II) as evidenced by the occurrence of an extra fragment of $\sim 440$ base pairs and the absence of a fragment larger than the biggest Hpa II fragment of $\mathrm{pBR} 322$, the latter originating from the cleavage of the two pBR322 Hpa II sites marked in Figure 4. The $\sim 620$ base pair fragment obtained by Hpa II cleavage of the recombinant plasmid must be due to a fragment obtained by the cleavage of one site within and one site outside the insertion. The fact that this Hpa II fragment of the recombinant plasmid can also be cleaved with Eco RI shows it to span the Eco RI site and defines the location of the left Hpa II insertion site in Figure 4. The double digest of the recombinant plasmid with Hpa II and Hind III results in the $\sim 620$ base pair fragment and $\mathrm{a} \sim 330$ base pair fragment, which can only be derived with a second Hpa II cleavage site in the insertion as drawn in Figure 4. This explains the additional $\sim 440$ base pair fragment obtained with Hpa II alone and the two fragments obtained by the double digest with Eco RI ( $\sim 440$ and $\sim 460$ base pairs). If only two Hpa II cleavage sites with their location as defined would be present in the inserted sequence an additional fragment of 350 to 400 base pairs in expected. Since this was not found additional Hpa II sites are postulated in the center of the inserted sequence giving rise to small fragments not detectable in the present analysis.

\section{DISCUSSION}

The cloned $\sim 850$ base pair long cDNA sequence hybridized with mRNA for the 29 kilodalton B-hordein precursor polypeptide and at least partially with that of the 40 kilodalton Bhordein precursor polypeptide as shown by the hybrid-arrested translation experiment. The coding capacity of this sequence is large enough for the 29 kilodalton polypeptide but can only accommodate $70 \%$ of the information necessary for a 40 kilodalton polypeptide. The 29 kilodalton polypeptide is probably the precursor to one of the two polypeptide bands comprising the B1hordein. Peptide mapping of the Bl-hordein established both differences and homologies to the other B2 and B3-hordein polypeptides (17, 20 ). The 40 kilodalton polypeptide is likely to be the precursor of the B2-hordein characterizer previously (17). It is clear from the present results that the different $\mathrm{B}$-hordein polypeptides are translated from different mRNA molecules. For the time being it is most likely that the structural homology between the B-hordein polypeptides is the reason for the partial arrested translation of the 40 kilodalton polypeptide by the cloned sequence for the 29 kilodalton polypeptide. From the present results it is expected that separate messenger RNA molecules and consequently separate genes code for the 8-10 identified B and C-hordein polypeptides. The present and additional sequences transcribed and cloned from isolated hordein messenger RNA molecules can be used to explore how many genes are present in the hor-2 region of chromosome $5(12,22,24,26)$ coding for the Bhordein polypeptides. Analogously cloned sequences for the C-hordein polypeptides can be used to analyse the hor-l region of chromosome 5 considered to code for the $\mathrm{C}$-hordein polypeptides.

The restriction enzyme analysis of the cloned sequence lends support to its coding capacity for a hordein polypeptide. These proteins are characterized by a high content of proline (22\%), which is coded for by GGX. The recognition sequence for Hpa II is GGCC thus giving a good chance for such cleavage sites in hordein sequences. A proline codon of GGC and a neighbour codon for valine, alanine, aspartic acid, glutamic acid or glycine, which comprise at least $15 \%$ of the constituent amino acids would result in a Hpa II cleavage site. The fragment sizes recovered from the digestions with Hpa II of the recombinant plasmid indeed indicated several Hpa II sites in the center of the inserted hordein sequence.

\section{ACKNOWLEDGEMENTS}

I thank professor DiTeR voN WeTtSTEIN for valuable discussions and critical reading of the manuscript. I am grateful to Lydia PAN, NINA Rasmussen, AnN-Sofl Steinholtz, Hanne NielSEN and LENA KongsRud for their skillful technical assistance. 


\section{REFERENCES}

1. Baulcombe. D. \& D. P. S. Verma: Preparation of a complementary DNA for leghaemoglobin and direct demonstration that leghaemoglobin is encoded by the soybean genome. Nucleic Acids Res. 5, 4I4I-4153 (1978)

2. Bolivar, F. R. L. Rodriglfz, P. J. Greene. M. C. Betlach, H. L. HeYneker \& H. W. Boyer: Construction and characterization of new cloning vehicles. Il A multipurpose cloning system. Gene 2, 95-113 (1977)

3. Boyfer, H. W. M. Betlach, F. Bolivar, R. L. Rodriguez. H. L. HeYNeKer, J. SHINe \& H. M. Goodman: The construction of molecular cloning vehicles. In: Recombinant molecules: Inpact on science and society, ed. R. F. Beers \& E. G. Basset, Raven Press, New York. pp 9-20 (1977)

4. Brandt, A. \& J. INGversen: In vitro synthesis of barley endosperm proteins on wild type and mutant templates. Carlsberg Res. Commun. 4I. 312-320 (1976)

5. Brandt, A. \& J. Ingversen: Isolation and translation of hordein messenger RNA from wild type and mutant endosperms in barley. Carlsberg Res. Commun. 43, 451-469 (1978)

6. Buell. G. N., M. P. Whekens. F. Payvar \& R. T. SCHIMKE: Synthesis of full length cDNA from four partially purified oviduct mRNAs. J. Biol. Chem. 253, 2471-2482 (1978)

7. Cameron-Mit.is, V.. J. Ingiversen \& A. Brandt: Transfer of in vitro synthesized barley endosperm proteins into the lumen of the endoplasmic reticulum. Carlsberg Res. Commun. 43, 91102 (1978)

8. Cameron-Mil.ls, V. \& J. Ingversev: In vitro synthesis and transport of barley endosperm proteins: Reconstitution of functional rough microsomes from polyribosomes and stripped microsomes. Carlsberg Res. Commun. 43, 471489 (1978)

9. Clewell, D. B.: Nature of colEl plasmid replication in Escherichia coli in the presence of chloramphenicol. J. Bacteriol. 110, 667-676 (1972)

10. Cl.ewell. D. B. \& D. K. Helinski: Supercoiled circular DNA protein complex in Escherichia coli: Purification and induced conversion to an open circular DNA form. Proc. Nat. Acad. Sci. L.S.A. 62, 1159-1166 (1969)

11. Devos, R., J. vax Emmelo, R. Contrerus \& W. FIERS: Construction and characterisation of a plasmid containing nearly full-size DNA copy of bacteriophage MS2 RNA. J. Mol. Biol. 128. 595-619 (1979)
12. Dot.. H. \& A. H. D. Brown: Hordein variation in wild (Hordeum spontaneum) and cultivated (H. vulgare) barley. Can. J. Genet. Cytol. (in press)

13. Fox. I. E.. H. M. Pratt. P. R. Shewry \& B. J. MIFLIX: The in vitro synthesis of hordeins with polysomes from normal and high-lysine varieties of barley. In: Nucleic acid and protein synthesis in plants. Paris: Center National de la Recherche Scientifique pp. 501-509 (1977)

14. Grunstein, M. \& D. S. Hogness: Colony hybridization: A method for the isolation of cloned DNAs that contain a specific gene. Proc. Nat. Acad. Sci. U.S.A. 72. 3961-3965 (1975)

15. Guidelines for research involving recombinant DNA molecules. Federal Register L'S.A.. 22 Dec. 1978 pp $60108-60313$

16. Higlchi, R., G. V. Paddock, R. Woll. \& W. SAISER: A general method for cloning eucaryotic gene sequences. Proc. Nat. Acad. Sci. U.S.A. 73 , 3146-3130 (1976)

17. Hol.der, A. A. \& J. Ingversex: Peptide mapping of the major components of in vitro synthesized barley hordein: Evidence for structural homology. Carlsberg Res. Commun. 43, 177-184 (1978)

18. IngVERSEN, J.: Structure and composition of protein bodies from wild type and high lysine barley endosperm. Hereditas 81. 69-76 (1975)

19. Lederberg. E. M. \& S. ... CoheN: Transformation of Salmonella typhimurium by plasmid deoxyribonucleic acid. J. Bacteriol. 119. 1072$1074(1974)$

20. MifLiN, B. J. \& P. R. Shewry: The biology and biochemistry of cereal seed proteins. In: Seed protein improvements in cereals and grain legumes. Proc. of a sumposium. IAEA Vienna. STI/PLB/496 pp. 137-158 (1979)

21. Miflin, B. J. \& P. R. Shewry: The synthesis of protein in normal and high lysine barley seeds. In: Recent advances in the biochemistry of cereals. Ed. D. L. Laidman \& P. G. Wyn Jones. Academic Press, pp. 239-27I (1979)

22. Oram, R. N., H. Doll. \& B. Kole: Genetics of two storage protein variants in barley. Hereditas $80,53-58(1975)$

23. Patterson, B. M., B. E. Roberts \& E. L. Klff: Structural gene identification and mapping by DNA mRNA hybrid-arrested cell-free translation. Proc. Nat. Acad. Sci. L.S.A. 74, 43704374 (1977)

24. Shewry, P. R., H. M. Pratt, R. A. Finch \& B J. Mifin: Genetic analysis of hordein polypeptides from single seeds of barley. Heredity 40 . 463-466 (1978) 


\section{A. Brandi: Hordein cDNA}

25. Shewry, P. R., J. K. S. El.lis, H. M. Pratt \& B. J. MifLIN: A comparison of methods for the extraction and separation of hordein fractions from 29 barley varieties. J. Sci. Food. Agric. 29. 433-441 (1978)

26. Solari, R. M. \& E. A. Favrei: Polymorphism in endosperm proteins of harley and its genetic control. In: Proc. 2. Int. Barley Genet. Symp. Ed. R. A. Nilan, Washington State Univ. Press p. 23-31 (1971)

27. Suicuiffk, J. G.: pBR322 restriction map derived from the DNA sequence: Accurate DNA size markers up to 4361 nucleotide pairs long. Nucleic Acids Res. 5, 2721-2728 (1978)
28. Wetistein, D. von: Biochemical and molecular genetics in the improvement of malting barley and brewers yeast. Proc. Eur. Brewery Conv. Congr.. Berlin (in press) (1979)

29. Weinard, V., C. Brüschke: \& G. Feix: Cloning of double stranded DNAs derived from polysomal mRNA of maize endosperm: Isolation and characterisation of zein clones. Nucleic Acid Res 6. 2707-2715 (1979)

30. Wickens, M. P., G. N. Blhi. \& R. T. SChimk: Synthesis of double-stranded DNA complementary to lysozyme. ovomucoid and ovalbumin mRNAs. J. Biol. Chem. 253. 2483-2495 (1978)

31. Zasioff. M., G. D. Guider \& G. Felsenfei.d: A new method for the purification and identification of covalently closed circular DNA molecules. Nucleic Acid Res. 5. 1139-1151 (1978) 